\title{
（No.27 白血球）
}

\section{白血球, 藏器特異性二就亏}

（寉題「䑏器特異性二關スル研究」實驗成績其二十七, 白血球二就 $゙$ ）

京都帝國大學醫學部微生物學教室

\section{植田秀嶺 - 三好毅一}

目次

第 1 笪 緒 論

第 2 章 白血球探取方法

第 3 章 貫驗成績

第 1 節 沈降反㗂ニヨル白血球ノ臟器特黑性

第 2 節 補體結合反應 $ニ コ ル$ 白血球 $>$ 臟器特

異性

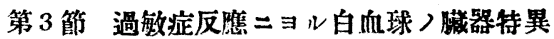
性

第 4 章 結 論

主要交献

\section{緒 言}

近特組織及ビ藏器ノ特異性二關スル知見大二加ッテ來タガ，白血球二就テン 餘り研究サレテ居ナイ。從ッテ其ノ特異性ニッイテハ, 佾幾多ノ疑義 居ル．Leschke $e_{(1)}$ 八人及ビ馬ノ白血球二テ處置シタル家兔〉血清ニッイテ，其， 凝集反應細胞溶解現象補體結合反應 7 檢查シ夕結果, 白血球二八種屬特異性ノ アル事ヨ知ッタ. S pät.(2) 、Leschke 八說习磪メタル外, 海猽白血球充疫家兔 血清ハ海埧, 白血球ノミナラズ, 肝臟腎臟ノ細胞トモ反應シ且ッ此等細胞ノ何 レニョリテモ血清中ノ抗體ハ完全二吸收セラル、故白血清ニハ臟器特異性ハナ イト云ッタ. Rosenthal u. Fallenheim(3) 八人ノ白血球デ货投シタ家鬼血清二就 シ檢查シテ白血球ト血小板ハ近親デアルト云ッタ.

Hektoen and Manne $(4)$ メ犬, 海㺍, 人ノ白血球先疫家鬼血清ニッイテコレ等動 物白血球ノ相互關係及ビ血清, 赤血球, 血小板卜ノ關係 $习$ 研究シテ白血球》種屬 站. 臟器特異性ガアルト云ッタ。然レ共以上諸家ノ研究方法及ビ研究成績ニッ イテハ幾多，缺點ト不備ト不滿ヨ感ズル，且又未父綜合的二廣ク諸藏器卜ノ關 係习檢查シタモノガナイ。我々八絕好ノ機會二際會シテ，白血球特異性ニッキ 
可ナリ廣範二檢查スル事ガ出來タ.

\section{第 2 章白血球採取方法}

白血球 テハ動物皮下又、腹腔胸腔二諸種ノ物質 集メ. 或入化膿病後ョリ探取スル方法ガアルガ, 我々ノ㷪合ニハ行七難ク又斯 ルモノョリ純粹二探取スル事ハ不可能デアル。次二又拘椂酸曹達血液ヨリ探取 スル方法ガアルガ，之二依ル時ハ血小板ノ混入 7 防グ事ガ出氷ナイ。

我々ノ用ヒタル方法、Hamburger u. Helma ${ }_{(5)}$ ノ方法デアル, 屠境二於テ牛， 頸動脈ヨリ进出スル血液 $\ni$ 硝子玉 $ヨ$ 大レタ大瓶二探取シ，巧二振燙スル然ル時 八血小板ハ悉クふいぶりん塊二吸着セラル。斯ルモノ 7 速カ $=3,000$ 回々轉

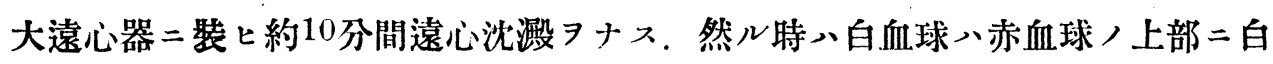
キ塊狀ヨナシラ集合スル，斯ルモノ 轉, 遠心器二約 1 分間裝フ。斯クスレバ白血球ハ大塊二集合シテ管底二沈澱シ

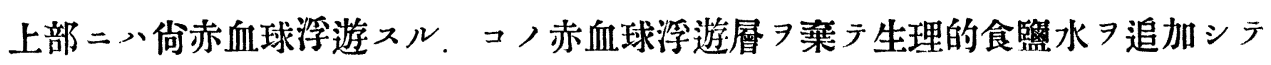
良ク混和シ一樣，浮遊液トナシテ再ビ遠心器二裝り。斯ル裝作 7 數回反復スル

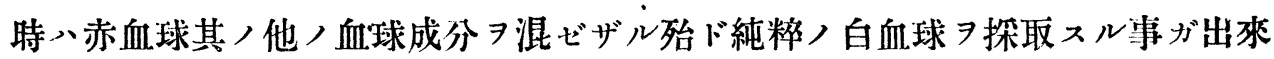
ル. 脫纎維血液 $50000 \%$ ヨ約 $20 \%$ 白血球ガ集ル。

斯クノ如クシテ得タル白血球ハ大凡次ノ組成 $习$ 有スル

中性顆粘白血球

淋 巴細 胞

总をじん㖺好性細胞

大單核細胞及ビ移行型

胞 㭌 細 胞
$53.0 \%$

$42.0 \%$

$3.5 \%$

$1.0 \%$

$0.5 \%$

之ヨめるく會社製海砂 加へ良ク磨碎シテ, 㭘微鏡二テ白血球ノ形態ノ存ゼザ

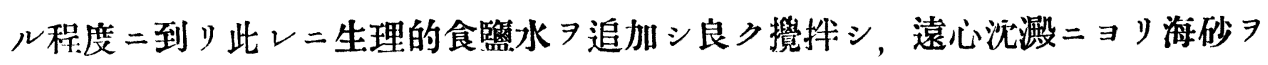
分離ス。斯クシテ得タル白血球越幾斯 トシテ實驗ニ供シタ。 


\section{第 3 章 實 駘 成 綪}

\section{第 1 節 沈降反應ニヨル熼器特哄性}

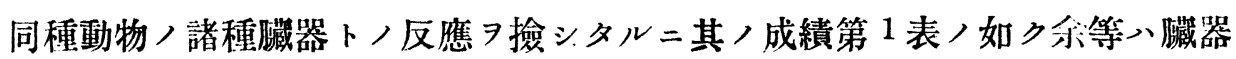
特異性 ヨ殆ンド證明シ得ナカッタ。白血球二近親關係 $コ$ 有スルモノ八淋巴腺, 脾臟，骨髓，胸腺，肺藏、·皮虐，血清，大腸粘膜，卵巢，小腸粘膜，子宮粘膜 デアッテ全ク關係ヨ有シナイモノ八血色素，ちれおぐぶろらんデアル，又反應 甚ダ弱イモノ八攝護腺，水晶體，硝子體，䑏臟，睪九，副腎，甲狀腺，胵粘膜 デアル其ノ他八中程度二反應シタ。

第 1 表 沈 降 反 應

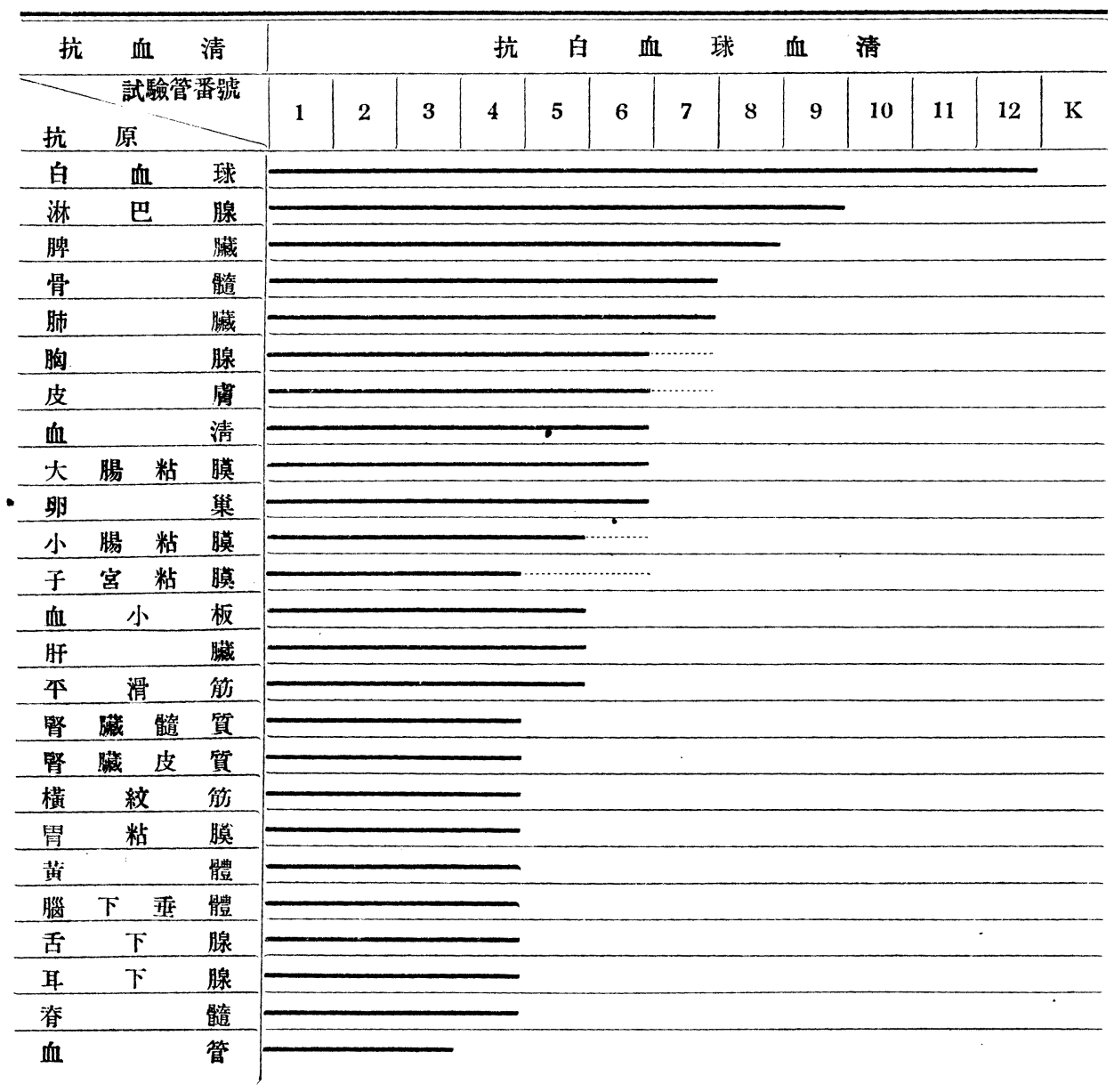




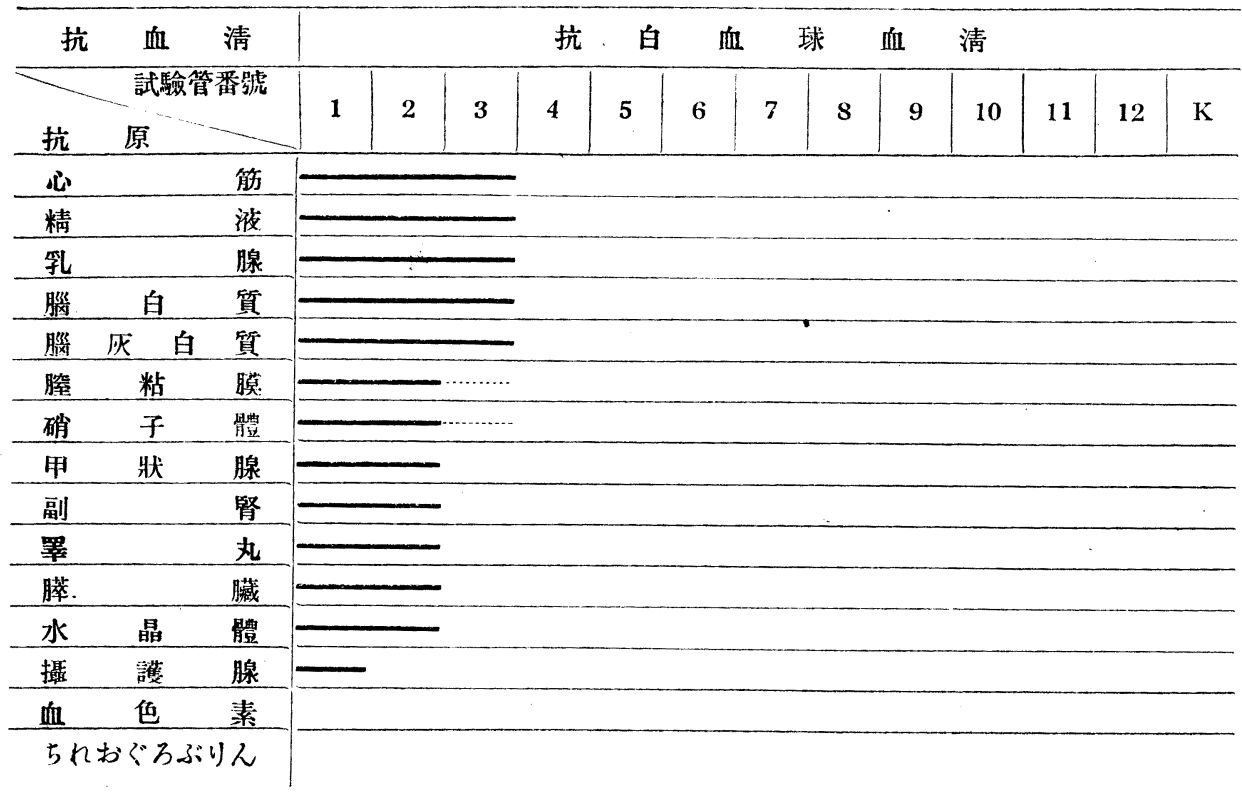

\section{第 2 節補體結合反瞧ニヨル特巽性}

本反應ニョリテモ臟器特異性 ヨ示サナイ.

最モ近親關係ヨ有スルモノ八溸巴腺，脾臟，肺藏，胸腺デテッテ，父應 サナイモノ八血色素，甲狀腺，ちれ就ぐろ九，䐙臟デアル，友應ノ甚ダ弱イ モノ八血清, 血管. 副腎, 水晶體デ其他ハ中程度二反應シタ.

第 2 表 補體 結合反應

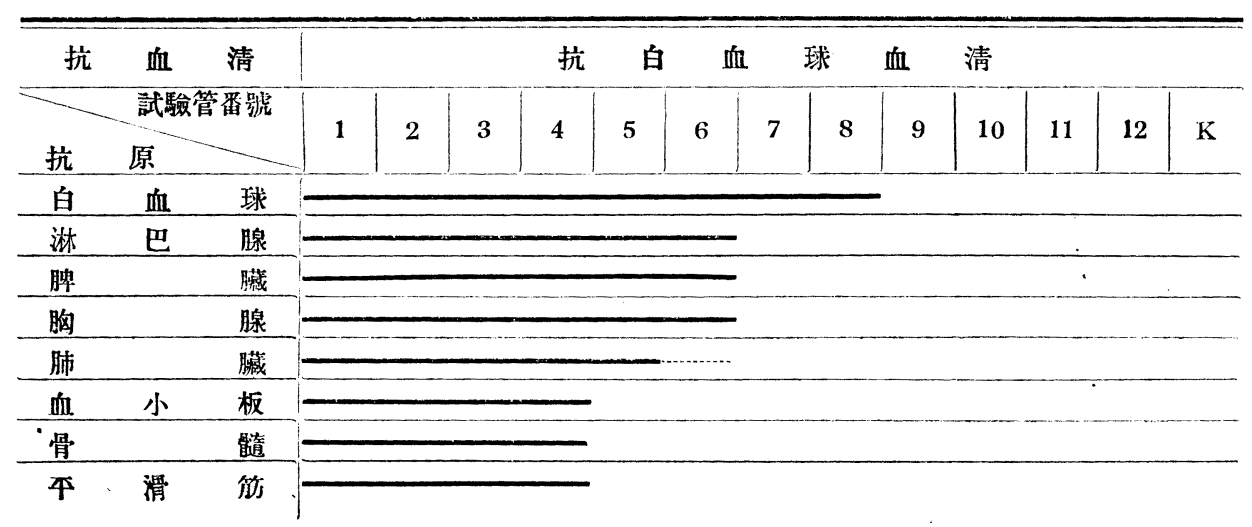




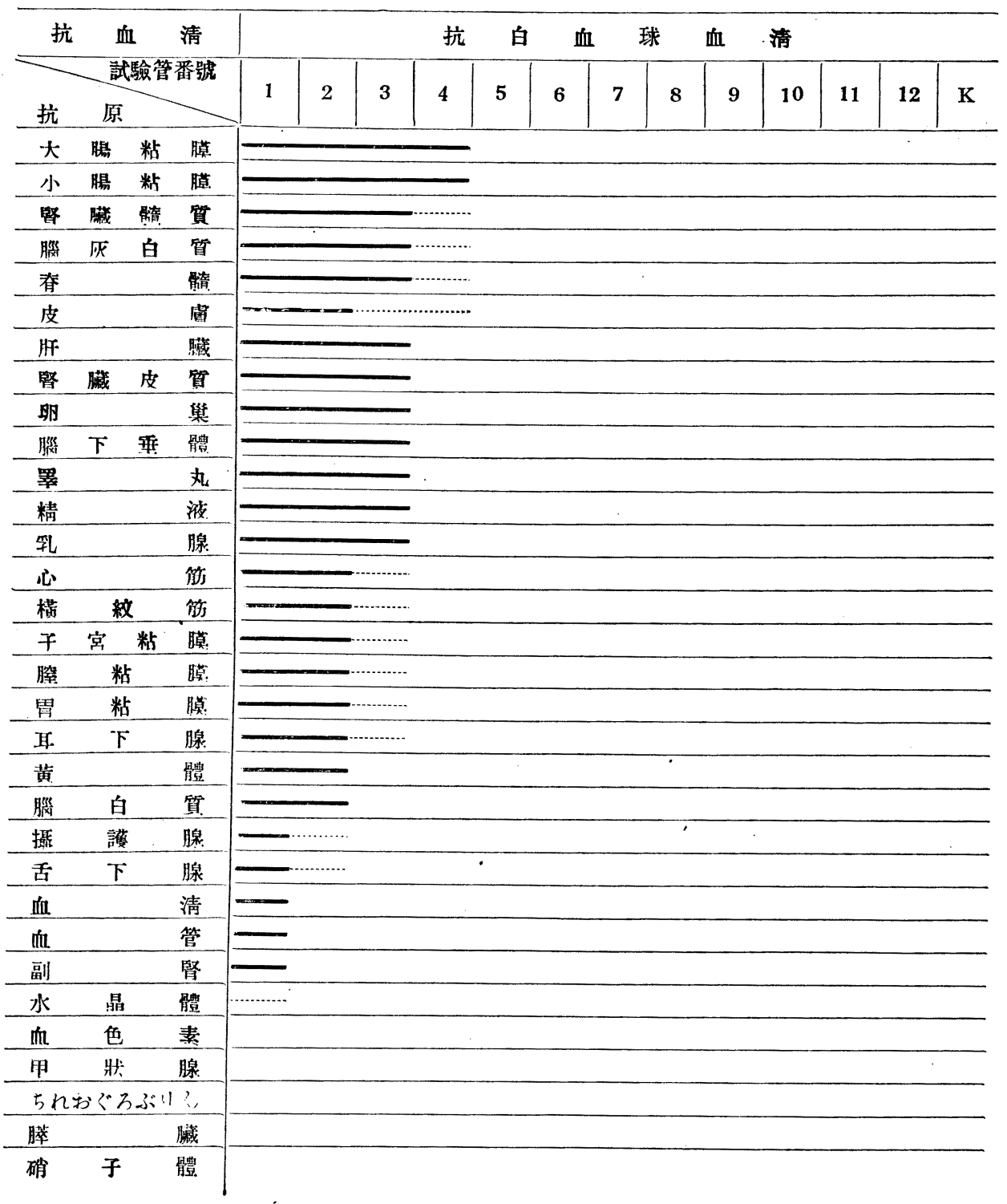

\section{第 3 節 過敏症反锥}

體重 $210 \mathrm{~g}$ 前後ノ海㺍 7 選ビ抗血清 7 泩射シテ 12 時間乃至 18 時間後一定量 抗元泩射 $・$ 行七受働性過敏症反應 應二テ反應著明ナ白血球，淋巴腺，腺瀻，肺臟小陰性ナルちれおぐろぶらんト

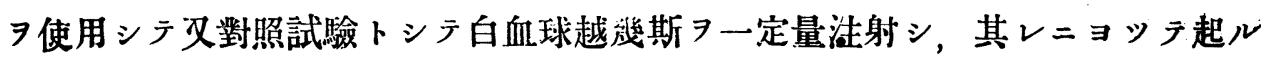


體温ノ戀化 7 見タ。

爾他 ノ藏哭越幾斯ノ注射 $=ョ ル$ 體温變化, 對照試驗 八同僚諸兄, 實驗 トシタ。

其ノ成績第 3 表ノ如クナッタ.

第 3 表

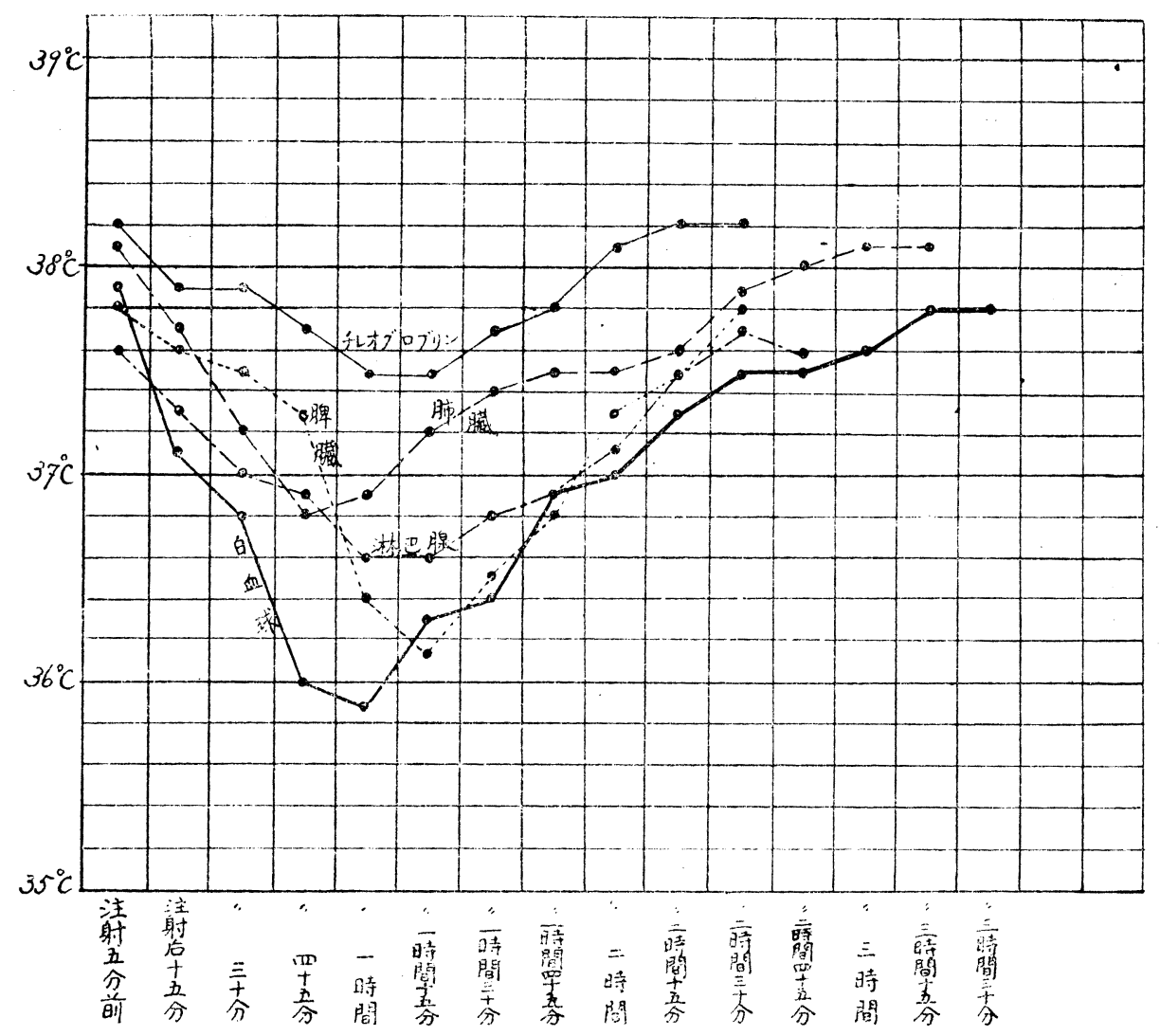

今白血球越幾斯 $/$ 腹腔內泩射 $=ヨ ル$ 體温, 戀化 7 見ル二大體二於テ泩射後暫

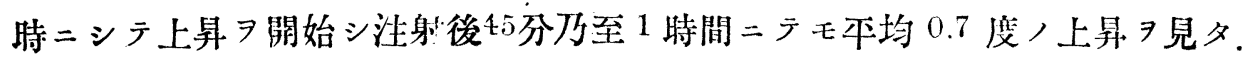
其レヨリ漸次下隆シ 2 時間前後二テ正常二復シタ.

次二抗血清泩射後所定, 時間二至り白血球越戌斯 温下降最モ甚がシク脾蕗，淋巴腺，肺臟越幾斯 $\ni$ 注射七ルモノニ於テモ稍著明 ニ下降 見タ. 


$$
\text { 植田秀䝷 - 三好毅 - 逊 }
$$

一般二泩射後 1 時間万至 1 時間 15 分ニシテ最低ニ達シテ其レヨリ漸次上昇シ 注射後 4 時間前後二至》正常二回復シタ.

本表 $ヨ$ 按ズルニ臟器越幾斯單獨泩射ニアッテハ, 差シタル變化

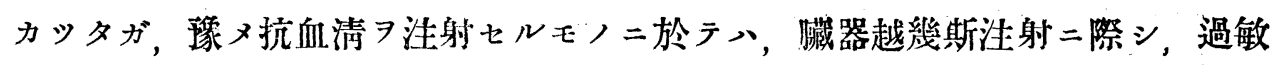
症状ガ著明二發現シタ。其ノ體温下降, 狀態ニョッテ, 被檢䁍器特異性 スル , 脾藏, 淋巴腺, 肺㶓二近親關係 $コ$ 示シ, 沈降反應補體結合反應 $=ョ リ$, 全然陰性ナルちれおぐろぶらんモ唯僅二反應ヨ表シタ.

\section{總括 及ビ結鯩}

（1）我々ガ實驗的二用七タ白血球，抗元，反應元八前記／如キ諸種型／集合 セルモノデアルカラ，從ッテ得タ實驗ハ概括的ノモノデアル嚴密ナル白血球特 異性 知ラントスルニ八各型白血球 7 純粹二多量二（例へバ培養法ニョリテ） 得タルモノタ以テ實驗シナケレバナラナイ。

(2) 余等八Bedsen ${ }_{(6)}$ Hektoen and Manne(4) 等ノ認メタルガ如キ白血球ノ臟 器特異性 7 認メナイ又 Rosenthut u. Falkonhoim 八如ク血小板卜ノ特別 近親關 係一認メナカッタ.

（3）沈降反應ニョッテ著シキ近覣關係ヨ示セルモノ八淋巴腺，骨髓，脾臟胸 腺，肺㶓，皮膚デアッテ全ク反應ナキモノ八血色素，ちれおぐろぶらんデアッ 夕.

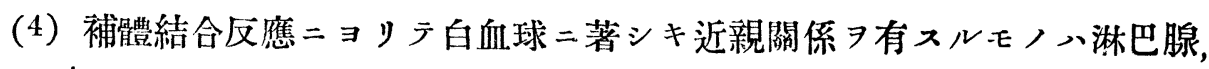
瑰藏, 胸腺, 肺臟デアッタ。全ク反應ナキモノ八血色素, 脾臟, 甲狀腺, ちれお ぐろぶらん，确子體デアッタ。

(5) 過敏症反應ニョリテモ又明カニ相互間，血清學的差異 7 制定セラレタ.

(6) 白血球血清ガ從來欌器特異性アリト考ェラレタ硝子體, 水晶體卜反應七 ルハ興味アルコトデアル.

\section{主要 文 献}

1) Leschke, E. Ueber Leucocytenauflc̈sende Immunstoffe. Zeitschr. Imm. Orig, Bd. 16, 1912. S. 627.

2) Spät, Wilhelm; Untersuchungen über ein

Leucocytenimmunserum. Zeitschrif, Immn. Orig., Bd. 21, 1914. S. 565. 
3) Rosenthal u. Falkenheim, Serolog. unters. üb d. struktur. u. Heikunft. d. Blntplättchen. Arch f. exp. Path u. Pharmak. 1922, Bd. 92.

4) Hektoen and F. R. Manne; Journ. A. m. A. Oct. 14.1922.

5) Hamburger u. Hekma. Biochem, Zeitschr. Bd. 3. p. 88, 1907.

6) Bedson. Blood-plate autisemm, its speufity a. role in the exp. production of Purpura. Jcurn. of pathol a. bact. 1921. No. 4. a. 1922. No. 1. 